\title{
Peningkatan hasil belajar mahasiswa melalui Metode quantum learning dengan teknik Mind mapping
}

\author{
Andi Mariani Ramlan \\ Universitas Sembilanbelas November Kolaka \\ Email: marianiramlan@gmail.com
}

(Received: Juni-2017; Reviewed: Juni-2017; Revised: Juli-2017; Accepted: Juli-2017; Published: Agustus)

\begin{abstract}
The purpose of this study is to improve the student learning outcomes in the course of Complex Analysis by applying Quantum Learning method with Mind Mapping technique. This research is conducted to give innovation method and technique of lecturer to reach the purpose and result of learning as expected. The research runs from September to December 2013 at the University of Sembilanbelas November Kolaka, Outheast Sulawesi. The subject of the reserach is the B grade students of class VII 2011 with a total of 34 students. This research is included in Classroom Action Research (CAR). The researchers designed the study in several cycles each cycle with stages: 1) Planning, 2) Implementation; 3) Observation and Evaluation, and 4) Reflection. The students responded is positively to learning by using Quantum Learning method with Mind Mapping technique. The students' learning achievement is 3,29 from the ideal value of 4,00; and 88,3\% Student get A Or B. Then, it is concluded that Quantum Learning method with mind mapping technique can improve student learning outcomes in Complex Analysis program.
\end{abstract}

Keywords: quantum learning and mind mapping

\begin{abstract}
ABSTRAK
Tujuan dari penelitian ini adalah untuk meningkatkan hasil belajar mahasiswa pada mata kuliah Analisis Kompleks dengan menerapkan metode Quantum Learning dengan teknik Mind Mapping. Penelitian ini diadakan untuk memberikan inovasi pada metode maupun teknik perkuliahan dosen untuk mencapai tujuan dan hasil belajar sebagaimana yang diharapkan. Penelitian ini berlangsung bulan September sampai Desember 2013 di Universitas Sembilanbelas November Kolaka, Sulawesi Tenggara. Kelas yang digunakan sebagai subyek penelitian adalah mahasiswa kelas B semester VII angkatan 2011 dengan jumlah 34 orang. Penelitian ini termasuk dalam jenis Penelitian Tindakan Kelas (PTK). Peneliti merancang penelitian ini dalam beberapa siklus yang masing-masing siklus memiliki tahap-tahap: 1) Perencanaan, 2) Pelaksanaan; 3) Observasi dan Evaluasi, serta 4) Refleksi. Hasil penelitian menunjukkan bahwa mahasiswa merespon positif terhadap pembelajaran yang menggunakan metode Quantum Learning dengan teknik Mind Mapping, prestasi belajar mahasiswa yang diajar dengan menggunakan metode dan teknik tersebut mencapai nilai rata-rata 3,29 dari nilai ideal 4,00, dan 88,3\% mahasiswa memperoleh nilai A atau B. Sehingga disimpulkan bahwa metode Quantum Learning dengan teknik Mind Mapping dapat meningkatkan hasil belajar mahasiswa pada mata kuliah Analisis Kompleks.
\end{abstract}

Kata Kunci: quantum learning dan mind mapping 


\section{PENDAHULUAN}

Dosen diemban tanggung jawab sebagai seorang pendidik diharapkan mempunyai sikap professional dalam memilih strategi, metode pembelajaran, dan teknik-teknik dalam mengarahkan mahasiswa berkompeten khususnya dalam pembelajaran matematika. Aspek lainnya, membangun karakter (character building) mahasiswa dengan segala keunikan dan keragaman sifat, cara belajar, pemahaman, dan latar belakang lingkungan sosial.

Pembelajaran matematika sangat berpengaruh terhadap keseluruhan proses mempelajari matematika di tahun-tahun berikutnya. Jika konsep dasar yang diletakkan kurang kuat atau anak mendapatkan kesan buruk pada perkenalan pertamanya dengan matematika, maka tahap berikutnya akan menjadi masa-masa sulit dan penuh perjuangan Setyono (2007:15-16).

Berdasarkan hasil pengamatan peneliti yang mengajarkan mata kuliah analisis kompleks bahwa penguasaan mahasiswa program studi pendidikan matematika untuk mata kuliah analisis kompleks di Universitas Sembilanbelas November Kolaka masih kurang. Hal ini dapat disebabkan beberapa hal diantaranya; a) Universitas Sembilanbelas November Kolaka dalam perubahan status menjadi negeri tergolong universitas baru berkembang yang berlokasi di kabupaten, sehingga dalam penerimaan mahasiswa baru masih menerima pendaftar dari jurusan non IPA, karena kurangnya peminat; b) mahasiswa bermasalah pada konsep dasar sebab tidak membiasakan diri melatih kemampuannya; c) mahasiswa sebagian dari keluarga menengah ke bawah, sehingga memiliki buku masih dinomorduakan. Karena banyaknya mahasiswa yang tidak memiliki buku, mengakibatkan dalam proses perkuliahan, dosen harus mendiktekan atau menuliskan definisi, teoremateorema, maupun materi yang lain selama memberi kuliah. Tentu saja hal ini sangat menyita banyak waktu.

Masalah-masalah yang dihadapi mahasiswa dalam memahami khususnya mata kuliah analisis kompleks di tahun sebelumnya dengan rata-rata nilai mahasiswa tidak sesuai harapan, kesulitan dalam memahami materi abstrak dalam matematika, dan pandangan negatif terhadap matematika dianggap sebagai momok sebagai faktor yang mempengaruhi keberhasilan seseorang dalam belajar, baik dari dalam diri mahasiswa maupun faktor dari luar. Sehubungan dengan penelitian yang dilakukan Sofnidar dan Rohati (2009:57) bahwa mahasiswa masih saja ada yang mengalami kesalahan dalam memilih konsep yang harus digunakan untuk menyelesaikan masalah dalam bilangan kompleks yang diberikan. Kesalahankesalahan tersebut antara lain mahasiswa sering menggunakan konsep-konsep pada bilangan riil untuk semua bentuk bilangan kompleks. Mahasiswa belum bisa mengkaitkan dan membedakan konsep-konsep yang sudah dipelajari pada mata kuliah kalkulus dan analisis riil sebelumnya dengan konsep-konsep pada mata kuliah analisis kompleks, terutama sekali tentang konsep dalam integral, karena integral fungsi kompleks merupakan integral fungsi sepanjang kurva dan banyak konsep-konsep atau teorema-teorema. Sehingga rata-rata hasil belajar mahasiswa secara klasikal masih cukup (nilai C).

Inovasi dalam dunia pendidikan salah satunya metode Quantum Learning, dikembangkan oleh Bobby DePorter yang beranggapan bahwa metode ini sesuai dengan cara kerja otak manusia dan cara belajar manusia pada umumnya. Pengajaran dengan Quantum Learning tidak hanya menawarkan materi yang dipelajari mahasiswa tetapi juga diajarkan menciptakan hubungan emosional yang baik dalam belajar. Dengan Quantum Learning kita dapat mengajar dengan memfungsikan kedua belahan otak kiri dan otak kanan pada fungsinya masing-masing. Dalam hal ini (Yurisaldi, 2010:12) mengemukakan otak kiri adalah pusat logika matematika, tempat berpikir yang memerlukan penjelasan mendetail atau deskriptif sedangkan otak kanan adalah pusat kegiatan berperasaan seni sekaligus pusat ide-ide kreatif. Penggunanan metode Quantum Learning perlu dipadukan dengan teknik tertentu yakni peta pikiran (Mind Mapping) untuk mendapatkan hasil belajar yang maksimal.

Peta pikiran (Mind Mapping) adalah teknik pemanfaatan keseluruhan otak dengan menggunakan citra visual dan prasarana grafis lainnya untuk membentuk kesan (DePorter dan Hernacki, 2013:153). Mind Mapping merupakan cara termudah untuk menempatkan informasi ke dalam otak dan mengambil informasi ke luar dari otak. Mind Mapping adalah cara mencatat kreatif, efektif dan secara harfiah akan memetakan pikiran-pikiran kita. Dengan Mind Mapping daftar informasi yang panjang bisa dialihkan menjadi diagram warna-warni, sangat 
teratur dan mudah diingat yang bekerja selaras dengan cara kerja otak dalam melakukan berbagai hal dikemukakan Fadhilaturrahmi (2017:114-115).

Mata kuliah Analisis Kompleks merupakan mata kuliah yang tergolong sebagai mata kuliah sulit di tingkat perguruan tinggi, menurut informasi dan pengalaman dalam memahami mata kuliah ini diperlukan konsep aljabar yang kuat pada operasi maupun aplikasinya pada bilangan imajiner.

Peneliti yang merupakan dosen untuk mata kuliah Analisis Kompleks di Universitas Sembilanbelas November Kolaka ingin melihat peningkatan mutu pendidikan khususnya pada mata kuliah Analisis Kompleks menggunakan metode Quantum Learning dengan teknik Mind Mapping, karena peningkatan mutu pendidikan merupakan salah satu unsur kongkrit yang sangat penting dalam upaya peningkatan kualitas sumber daya manusia. Berdasarkan latar belakang tersebut maka peneliti tertarik mengangkat judul penelitian "Peningkatan Hasil Belajar Mahasiswa melalui Metode Quantum Learning dengan Teknik Mind Mapping

Secara umum tujuan penelitian ini adalah untuk meningkatkan hasil belajar mahasiswa pada mata kuliah Analisis Kompleks menggunakan metode Quantum Learning dengan teknik Mind Mapping.

Quantum merupakan interaksi yang mengubah energi menjadi cahaya. Quantum Learning merupakan seperangkat metode dan falsafah belajar yang terbukti efektif untuk semua umur. Quantum Learning berakar dari upaya Georgi Lazanov, seorang psikolog yang berupaya mengembangkan prinsip yang disebut "suggestologi atau suggestopedia". Menurutnya sugesti dapat mempengaruhi hasil belajar dan setiap detail keadaan apapun memberikan sugesti positif atau negatif. (DePorter dan Hernacki, 2013:14).

Otak dapat dipandang sebagai hutan raya tempat puluhan ribu pohon dengan ratusan ribu cabang besar bahkan jutaan dahan dan miliaran ranting. Peta konsep dibuat dengan cara yang sama seperti halnya informasi disimpan pada cabang-cabang dari tema sentral meskipun skalanya jauh lebih kecil. Dalam menyusun peta konsep gaya pemrosesan belahan kiri dan belahan kanan otak dilibatkan secara penuh (Rose dan Nickall, 2002:136)

Hingga saat ini orang mengira bahwa otak mengolah informasi secara linier yaitu tersusun secara teratur dan rapi seperti sebuah daftar kata. Namun kini, para ilmuwan menyatakan bahwa itu adalah hasil bukan proses komunikasi. Saat orang berkomunikasi otak akan memilah semua informasi yang sifatnya beragam, acak dan rumit kemudian merangkaikannya menjadi lebih terstruktur dan rapi. Damasio (DePorter dan Hernacki 1999) mengemukakan bahwa dalam proses komunikasi otak lebih mudah mengingat informasi dalam bentuk gambar simbol suara bentuk-bentuk dan perasaan. Peta pikiran atau Mind Mapping menggunakan citra visual dalam bentuk tulisan simbol dan gambar serta warna. Mind Mapping menggunakan pengingatpengingat visual sensorik dalam suatu pola dan ide-ide yang berkaitan seperti peta jalan dalam teori ghrap yang digunakan untuk belajar, mengorganisasikan dan merencanakan. Peta ini dapat membangkitkan ide-ide orisional dan memicu ingatan yang mudah. Ini jauh lebih mudah dari pada metode pencatatan konvensional karena ia mengaktifkan kedua belahan otak yaitu otak kiri dan otak kanan (dalam Soekarno 2010:79).

Vos (2003) menyatakan secara umum otak kiri memainkan peranan penting dalam pemrosesan logika, kata-kata, dan urutan atau yang disebut sebagai otak yang berkaitan dengan pembelajaran akademis. Otak kanan berkaitan dengan irama, ritme, dan musik. Gambar dan imajinasi atau yang disebut sebagai otak yang berkaitan dengan aktivitas kreatif. Kedua belahan otak ini dihubungkan oleh corpus eollosum yang secara konstan menyeimbangkan pesan-pesan yang datang dan menggabungkan gambar yang abstrak dan holistic dengan pesan konkrit dan logis (dalam Soekarno 2010:79).

Pembuatan Mind Mapping cukup sederhana cukup satu lembar kertas dapat digunakan untuk merangkum banyak materi dan juga diperlukan pulpen atau spidol yang terdiri dari lebih satu warna. Menurut DePorter dan Hernacki (2013:157) berikut ini adalah tahapantahapan untuk membuat Mind Mapping: 1) di tengah kertas, dibuat lingkaran dari gagasan utamanya; 2) menanamkan sebuah cabang dan pusatnya untuk tiap poin kunci dengan tinta warna-warni; 3) menuliskan kata kunci pada tiap-tiap cabang dikembangkan untuk menambah detail-detail; 4) menambahkan simbol dan ilustrasi; 5) menggarisbawahi katakata yang penting; serta 6) membuat peta pikiran secara horizontal. 
Langkah-langkah pembelajaran Mind Mapping: 1) guru menyampaikan kompetensi yang ingin dicapai; 2) guru mengemukakan konsep atau permasalahan yang akan ditanggapi oleh mahasiswa dan sebaiknya permasalahan yang mempunyai alternatif jawaban; 3) membentuk kelompok yang anggotanya 2-4 orang; 4) tiap kelompok menginventarisasi atau mencatat alternatif jawaban hasil diskusi; 5) tiap kelompok (atau diacak kelompok tertentu) membaca hasil diskusinya dan guru mencatat di papan dan mengelompokkan sesuai kebutuhan guru; 6) dari data-data di papan siswa diminta membuat kesimpulan atau guru memberi perbandingan sesuai konsep yang disediakan guru. Siswono (2009) dalam (Soekarno 2010:80-81).

\section{METODE}

Ditinjau dari bagaimana penelitian ini dilakukan, maka penelitian ini termasuk dalam jenis penelitian tindakan kelas (PTK).

Subjek penelitian ini adalah mahasiswa program studi pendidikan matematika angkatan 2011 tahun akademik 2013/2014 Universitas Sembilanbelas November Kolaka.

Sebelum melaksanakan penelitian, peneliti melakukan kegiatan pendahuluan mencakup identifikasi dan analisis masalah. Dalam tahapan ini peneliti bersama dengan dosen mitra berdiskusi dan melakukan refleksi tentang masalah pembelajaran yang dialami mahasiswa, kemudian memilih kelas yang hasil belajarnya rendah dan menetapkan alternatif tindakan untuk mengatasi masalah yang dihadapi yaitu penggunaan metode Quantum Learning dengan teknik Mind Mapping.

Beranjak dari kegiatan pendahuluan, peneliti merancang penelitian ini dalam beberapa siklus yang masing-masing siklus memiliki tahap-tahap sebagai berikut:

1. Perencanaan Tindakan

2. Pelaksanaan Tindakan

3. Observasi dan evaluasi

4. Refleksi

Penelitian tindakan kelas ini disesuaikan dengan perubahan yang ingin dicapai pada faktor-faktor yang akan diselidiki dan disesuaikan dengan cakupan materi dan alokasi waktu yang diberikan untuk mengajarkan kompetensi dasar Sistem Bilangan Kompleks dan Fungsi Analitik. Untuk mengetahui kemampuan dasar mahasiswa sebelum diberikan tindakan, maka diberikan tes awal yang berfungsi sebagai penghantar untuk melihat kemampuan dasar mahasiswa berkaitan dengan kompetensi dasar yang akan digunakan.

Prosedur tiap tahapan-tahapan penelitian tindakan kelas dalam tiap siklus, kegiatan yang dilakukan dalam tahapan:

1) Membuat dan menyusun skenario pembelajaran berupa SAP (Satuan Acara Perkuliahan) sesuai dengan metode dan teknik pembelajaran yang digunakan.

2) Membuat angket atau instrumen untuk respon mahasiswa terhadap penggunaan metode Quantum Learning dengan teknik Mind Mapping.

Peneliti dalam tahapan kegiatan pembelajaran melaksanakannya berdasarkan perencanaan yang telah disusun dalam SAP dengan memaksimalkan penggunaan metode pembelajaran dan teknik yang tepat.

Peneliti yang bertindak sebagai pengajar dibantu oleh pengamat (observer) dari luar yaitu teman sejawat atau dosen mitra. Observasi terhadap pelaksanaan tindakan dilakukan dengan menggunakan lembar observasi yang telah dibuat untuk melihat dan mengamati aktivitas belajar mahasiswa dan aktivitas peneliti yang bertindak sebagai dosen.

Pada akhir pembelajaran, peserta didik diberikan evaluasi hasil belajar yang bertujuan untuk mengetahui sejauhmana penguasaan mahasiswa terhadap materi yang diberikan.

Data yang dikumpulkan selama tindakan berlangsung kemudian dianalisis. Berdasarkan hasil analisis, dosen melakukan refleksi. Hasil refleksi akan membuat dosen menyadari tingkat keberhasilan atau kegagalan yang dicapai dalam tindakan perbaikan. Hasil refleksi ini merupakan masukan bagi peneliti dalam merencanakan dan melaksanakan tindakan perbaikan berikutnya. Kelemahan atau kekurangan yang terjadi pada siklus I akan diperbaiki pada siklus II.

Penggunaan metode dan teknik pembelajaran dikatakan berhasil jika:

1. Respon dikatakan positif, apabila rata-rata persentase setiap aspek berada dalam kategori senang, berminat, atau tidak kesulitan $\geq 70 \%$.

2. Hasil belajar mahasiswa meningkat dilihat dari Siklus I dan Siklus II

3. Ketuntasan hasil belajar.

Hasil belajar dikatakan tuntas jika $75 \%$ dari jumlah mahasiswa yang mengikuti perkuliahan memperoleh nilai B atau A.

Data dan teknik pengumpulan data dalam penelitian ini diantaranya: 
1. Sumber data yaitu mahasiswa.

2. Jenis data yang digunakan dalam penelitian ini adalah data kuantitatif berupa hasil belajar mahasiswa, dan data kualitatif berupa respon mahasiswa.

3. Teknik pengambilan data

Data mengenai hasil belajar matematika mahasiswa, diambil dengan menggunakan tes hasil belajar yang hasilnya dalam bentul nilai akhir mata kuliah Analisis Kompleks siklus I dan sikus II. Data mengenai respons mahasiswa diperoleh dengan menggunakan angket.

Instrumen dalam penelitian ini, yaitu:

1. Tes hasil belajar. Tes dalam penelitian ini disusun dalam bentuk essay test (tes uraian). Bentuk essay test terbagi atas Mid Tes dan Final Tes.

2. Angket respon mahasiswa. Angket respon mahasiswa disusun untuk mengetahui respon mahasiswa terhadap perkuliahan dengan menggunakan metode Quantum Learning dengan teknik Mind Mapping.

Teknik analisis data yakni:

1. Nilai yang digunakan adalah nilai yang berlaku di perguruan tinggi, yaitu nilai $\mathrm{A}=4$, $\mathrm{B}=3, \mathrm{C}=2, \mathrm{D}=1$, dan $\mathrm{E}=0$.

2. Menentukan rata-rata nilai hasil tes dengan menggunakan rumus:

$$
\bar{x}=\frac{\sum x i}{n}
$$

Dimana:

$$
\begin{aligned}
\bar{x} & =\text { Nilai rata-rata } \\
X_{\bar{i}} & =\text { Nilai } \mathrm{X} \text { ke } 1 \text { sampai ke } \mathrm{n} \\
\mathrm{N} & =\text { Jumlah individu }
\end{aligned}
$$

3. Menentukan tingkat pencapaian ketuntasan belajar mahasiswa dengan menggunakan rumus:

$$
\% \text { tuntas }=\frac{\sum x i}{n} \times 100 \%
$$

Dimana:

$$
\begin{aligned}
\sum f_{i}= & \text { Jumlah mahasiswa pada kategori } \\
& \text { ketuntasan belajar (Nilainya A atau B) } \\
\mathrm{N}= & \text { Jumlah mahasiswa }
\end{aligned}
$$

\section{HASIL DAN PEMBAHASAN}

\section{Hasil}

1. Data Belajar Analisis Kompleks

Data hasil belajar analisis kompleks baik pretest maupun posttest mahasiswa yang diajar dengan menggunakan metode Quantum Learning dan teknik Mind Mapping secara lengkap dapat dilihat pada tabel 4.1 berikut:
Tabel 4.1 Rekapitulasi Hasil Belajar Analisis Kompleks

\begin{tabular}{ccccc}
\hline \multirow{2}{*}{ Nilai } & \multicolumn{2}{c}{ Siklus I } & \multicolumn{2}{c}{ Siklus II } \\
\cline { 2 - 5 } & Mean & Persentase Frekuensi Persentase \\
\hline A & 11 & $32,4 \%$ & 14 & $41,2 \%$ \\
\hline B & 15 & $44,1 \%$ & 16 & $47,1 \%$ \\
\hline C & 8 & $23,5 \%$ & 4 & $11,8 \%$ \\
\hline D & 0 & $0,0 \%$ & 0 & $0,0 \%$ \\
\hline E & 0 & $0,0 \%$ & 0 & $0,0 \%$ \\
\hline
\end{tabular}

Deskripsi hasil belajar analisis kompleks mahasiswa pada siklus I dan siklus II dapat dilihat pada tabel 4.2 berikut

Tabel 4.2 Deskripsi hasil belajar Analisis

Kompleks

\begin{tabular}{ccc}
\hline Deskripsi & Siklus I & Siklus II \\
\hline $\mathrm{N}$ & 34 & 34 \\
\hline Mean & 3,0882 & 3,2941 \\
\hline Median & 3,0000 & 3,0000 \\
\hline $\begin{array}{c}\text { Standar } \\
\text { Deviasi }\end{array}$ & 0,75348 & 0,67552 \\
\hline Range & 2,00 & 2,00 \\
\hline Min & 2,00 & 2,00 \\
\hline Maks & 4,00 & 4,00
\end{tabular}

2. Respons Mahasiswa

Berdasarkan jawaban mahasiswa yang tertuang dalam angket respon mahasiswa terhadap perkuliahan yang meliputi pendapat dan perasaan mahasiswa mengenai materi perkuliahannya, cara belajar, dan cara dosen mengajar. Dari angket ini juga diperoleh minat siswa, dan kemajuan yang dirasakan siswa setelah pembelajaran. Respon mahasiswa terhadap pembelajaran dapat dilihat pada Tabel 4.3 berikut:

Tabel 4.3 Hasil Respons Mahasiswa terhadap Penerapan Pembelajaran

\begin{tabular}{llcc}
\hline \multirow{2}{*}{ No } & \multicolumn{1}{c}{ Indikator } & \multicolumn{2}{c}{ Respon Mahasiswa } \\
\cline { 2 - 3 } & & Frekuensi & $\begin{array}{c}\text { Persentase } \\
(\%)\end{array}$ \\
\hline 1 & Perasaan & & \\
& mahasiswa & & \\
terhadap materi & & \\
& pelajarannya & & 14,7 \\
& $\begin{array}{l}\text { a. Sangat Senang } \\
\text { b. Senang }\end{array}$ & 5 & 52,9 \\
& c. Biasa Saja & 18 & 32,4 \\
& d. Tidak Senang & 0 & 0 \\
\hline 2 & Perasaan & & \\
& mahasiswa & & \\
\hline
\end{tabular}




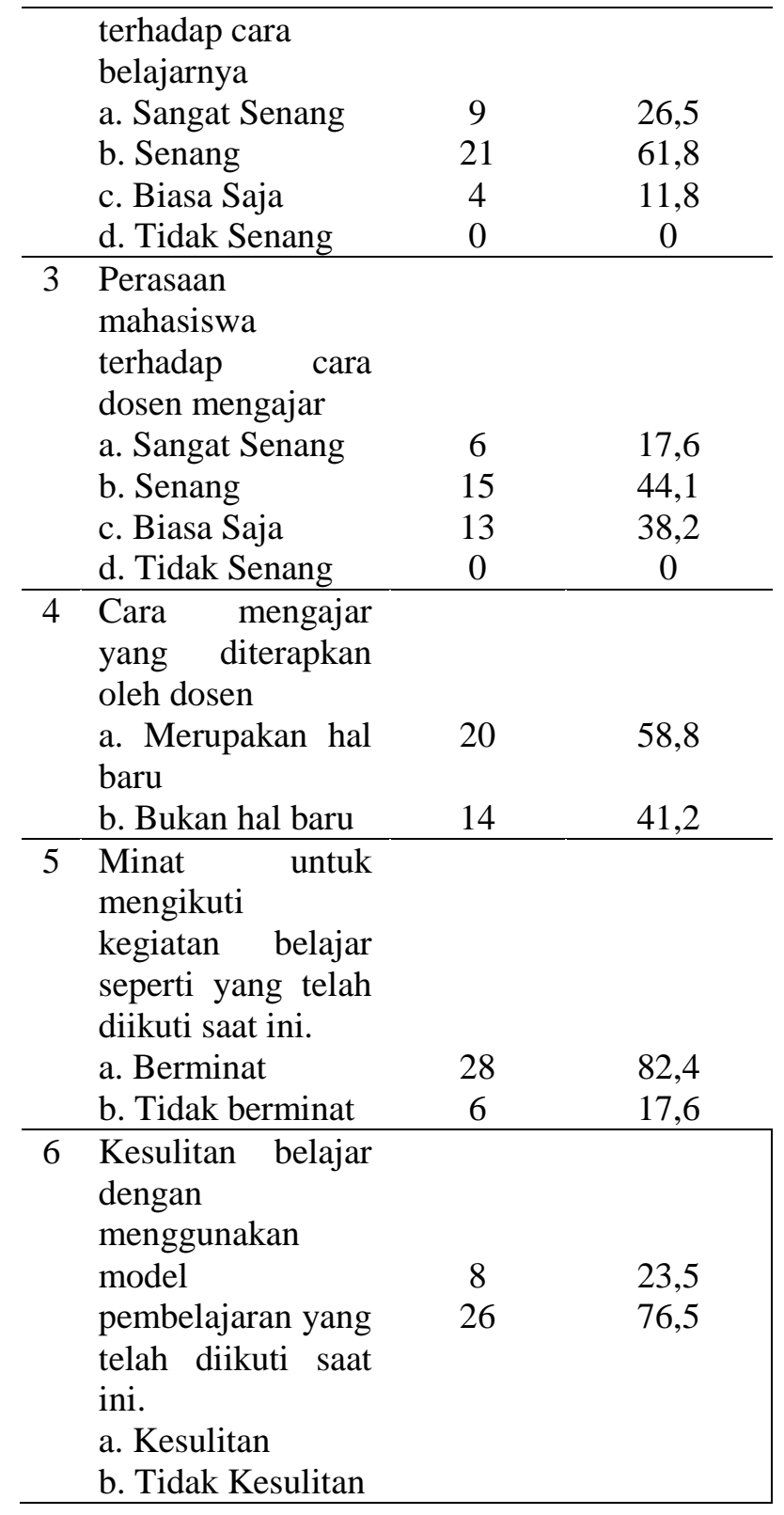

\section{Pembahasan}

Berdasarkan tabel 4.1 terlihat bahwa hasil belajar mahasiswa setelah diajar dengan menggunakan metode Quantum Learning dengan teknik Mind Mapping mengalami peningkatan di siklus yang berlangsung. Hal ini dapat dilihat dari peningkatan yang terjadi pada mahasiswanya yang mendapat nilai A dari 11 mahasiswa menjadi 14 mahasiswa, nilai B dari 15 mahasiswa menjadi 16 mahasiswa. Dimana, mahasiswa yang mendapat nilai $\mathrm{C}$ menurun dari 8 mahasiswa menjadi 4 mahasiswa.

Dari hasil angket respon mahasiswa, semua aspek memenuhi kategori, yaitu rata-rata persentase respons mahasiswa setiap aspek berada pada kategori $\geq 70 \%$. Sehingga dapat dikatakan bahwa mahasiswa merespons positif proses perkuliahan menggunakan metode
Quantum Learning dengan teknik Mind Mapping. Sesuai teori dikemukakan DePorter dan Henacki (1999) dalam Soekarno (2010:78) bahwa metode Quantum dengan perpaduan Mind Mapping memungkinkan mahasiswa untuk menjadi lebih teratur mengembangkan pemahaman, menyimpan informasi lebih lama, dan memperoleh wawasan baru.

Hasil Pengujian Hipotesis penelitian untuk menguji apakah ada perbedaan signifikan nilai rata-rata sebelum dan setelah perkuliahan menggunakan metode Quantum Learning dengan teknik Mind Mapping maka dirumuskan hipotesis untuk menguji perbedaan rata-rata hitung, yaitu:

$\mathrm{H}_{0}=$ Kedua rata-rata populasi tidak berbeda secara signifikan

$\mathrm{H}_{1}=$ Kedua rata-rata populasi berbeda secara signifikan

Berdasarkan hasil uji paired samples test nilai t-hitung $=-2,231$ dengan $\mathrm{p}=0,0000$. Oleh karena $\mathrm{p}<0,05$, maka $\mathrm{H}_{0}$ ditolak, atau terdapat perbedaan yang signifikan antara nilai mahasiswa sebelum dan setelah diadakan perkuliahan menggunakan metode Quantum Learning dengan teknik Mind Mapping.

Berdasarkan hasil analisis deskriptif diperoleh $\mu_{1}=3,09$ (parameter nilai rata-rata mahasiswa sebelum diadakan perkuliahan menggunakan metode Quantum Learning dengan teknik Mind Mapping) dan $\mu_{2}=3,29$ (parameter nilai rata-rata mahasiswa setelah diadakan perkuliahan dengan menggunakan metode Quantum Learning dengan teknik Mind Mapping).

Karena terdapat perbedaan yang signifikan nilai rata-rata mahasiswa sebelum diadakan perkuliahan dengan menggunakan metode Quantum Learning dengan teknik Mind Mapping, maka dapat disimpulkan bahwa nilai rata-rata mahasiswa setelah diadakan perkuliahan dengan menggunakan metode Quantum Learning dengan teknik Mind Mapping lebih baik secara signifikan. Berdasarkan teori ini dengan sugesti mahasiswa dapat mempengaruhi hasil belajar dan setiap detail keadaan apapun memberikan sugesti positif atau negatif. (DePorter dan Hernacki, 2013:14).

Hasil analisis data menunjukkan bahwa nilai rata-rata yang diperoleh mahasiswa telah mencapai indikator keberhasilan yang ditetapkan, yaitu: hasil belajar dikatakan tuntas 
jika $75 \%$ dari jumlah siswa yang mengikuti perkuliahan memperoleh nilai $\mathrm{B}$ atau $\mathrm{A}$. Pencapaian ini menunjukkan tingkat kemampuan mahasiswa setelah mengikuti perkuliahan dengan menggunakan metode Quantum Learning dengan teknik Mind Mapping.

\section{SIMPULAN DAN SARAN}

Berdasarkan hasil penelitian dan pembahasan, maka dapat disimpulkan (1) Prestasi belajar mahasiswa yang diajar dengan menggunakan metode Quantum Learning dengan teknik Mind Mapping mencapai nilai rata-rata 3,29 dari nilai ideal 4,00 dan $88,3 \%$ mahasiswa memperoleh nilai A atau B. (2) Respon mahasiswa terhadap perkuliahan dengan menggunakan metode Quantum Learning dengan teknik Mind Mapping pada umumnya memberikan respon positif. (3). Penggunaan metode Quantum Learning dengan teknik Mind Mapping dapat meningkatkan hasil belajar mahasiswa pada mata kuliah Analisis Kompleks.

Berdasarkan hasil penelitian, diajukan saran yaitu bahwa dalam proses perkuliahan, diharapkan dosen dapat memanfaatkan metode Quantum Learning dengan teknik Mind Mapping. Bagi peneliti di bidang pendidikan, disarankan agar dapat melakukan penelitian untuk mata kuliah yang berbeda.

\section{DAFTAR RUJUKAN}

Arikunto, Suharsimi, dkk. (2009). Penelitian Tindakan Kelas. Jakarta: Bumi Aksara.

DePotter, Bobbi, dkk. (2010). Quantum Teaching. Bandung: Kaifa.

DePorter, Bobbi dan Mike Hernacki. (2013). Quantum Learning. Bandung: Kaifa.

Fadhilaturrahmi. 2017. Penerapan Metode Mind Mapping untuk Meningkatkan Hasil Belajar Mahasiswa Semester IIA PGSD Mata kuliah Pendidikan Matematika SD Kelas Rendah. Journal Cendekia: Jurnal Pendidikan Matematika Volume 1, No. 1, Mei 2017. 112-121.

Mursel dan Nasution. (2008). Mengajar dengan Sukses. Jakarta: Bumi Aksara.

Rose, Colin dan Malcolm J. Nickall. (2002). Acceleated Learning for $21^{\text {th }}$ Century. Bandung: Nuansa.
Sagala, Syaiful. (2010). Supervisi Pembelajaran.

Medan: Alfabeta.

Saminanto. (2010). Ayo Praktik PTK. Semarang: Rasail.

Setyono, Ariesandi. (2007). Mathemagics. Jakarta:

Gramedia Pustaka Utama.

Soekarno. (2010). Efektivitas Pembelajaran Kooperatif Tipe Stad dan Quantum Learning Mind Mapping Terhadap Prestasi belajar Matematika ditinjau dari Kesiapan Belajar Siswa Kelas XI IPA SMA Negeri di Kabupaten Magetan Tahun Ajaran 2009/2010. Tesis. USM. Surakarta.

Sofnidar dan Rohati. (2009). Penerapan Metode Resitasi dengan Model Peta Konsep untuk Meningkatkan Kemampuan Mahasiswa dalam Pembelajaran Analisis Kompleks. Jurnal Penelitian Universitas Jambi Seri Humaniora Volume 11, Nomor 1, Hal. 57-65 ISSN 0852-8349. Januari - Juni 2009.

Yurisaldi Saleh, Arman. (2010). 10 Cara Merevolusi Otak Kanan Anak. Yogyakarta: Media Pressindo. 